\title{
nature
}

5 February 1998 Volume 391 Issue no 6667

\section{Timely lessons in investment from a wealthy 'wonk'}

President Bill Clinton's budget proposal contains an important message for governments that are tempted to undervalue basic science, its crucible, the research university, and the importance of impartial peer review.

W hy, after five years of lukewarm support for basic scientific research, has the Clinton administration just proposed a generous budget which will invest an additional $\$ 2$ billion next year in the National Institutes of Health (NIH), the Department of Energy and the National Science Foundation (NSF; see pages 521-522)? One possibility is that the scientific community's own fightback, orchestrated by scientific societies after the 1995 threat of serious cuts in research funding, was largely responsible for the president's change of heart. Some have pointed out that President Bill Clinton was in danger of being outflanked on the issue by Republicans in the Congress, some of whom have called for substantial extra research funding. And the effectiveness and popularity of Harold Varmus, the director of the NIH, is noteworthy - although that hardly explains the good fortune of the other science agencies.

But a close examination of Clinton's increasingly vocal statements on science policy issues over the past two years points towards a more significant explanation of science's newly improved budget prospects. The president's speeches, and now his actions, suggest that Clinton, perhaps the most enthusiastic policy wonk ever to occupy the White House, has done to science what he likes to do best: hammered at the available political and economic data — and concluded that investment in research is a winner on both counts.

\section{Priority}

When Clinton and his vice-president Al Gore came to power in 1993, their priority in this arena was technology, not science. Their main initiative was the Advanced Technology Program at the Department of Commerce, which was supposed to provide $\$ 1$ billion a year to help corporations to exploit the country's science base, already felt to be strong. "Technology" came up repeatedly in speeches by both men and "science" not at all, and the inference was clear: science could look after itself, and it was the role of government to bridge the alleged gap between scientific and industrial innovation.

Clinton's great plans for technology support were frustrated by the Congress, which argued that they represent inappropriate intervention. But, notwithstanding the alleged gap, the economy of the United States powered ahead. At the same time, the German or Japanese economic models, with their heavy reliance on direct or indirect national support for technology, fell into disrepute. The world's economists turned to the United States: they saw flexibility in labour markets and sundry other intangibles. They also saw booming information technology and biotechnology industries, closely tied to top-class research universities. So did Clinton.

As governor of Arkansas (and as a Rhodes scholar at Oxford) Clinton had scant prior knowledge of the modern research university. But travelling around the United States as president, he could hardly miss these establishments. Although most of their money comes from government, their research activities are far more intimately linked to private-sector wealth generation than any government department or laboratory. From San Diego and Tucson to
Philadelphia and Pittsburgh, such institutions are now the largest employers in many US cities, as well as the hub of their cultural, intellectual and economic life. As Clinton toured the country during his 1996 campaign, it is little wonder that science and research began to permeate speeches in which he promised to build "a bridge to the twenty-first century" (see Nature 383, 566; 1996).

A parallel awakening stirred Republicans in the Congress. Last year, a bipartisan group of senators led by Phil Gramm (Republican, Texas) and Joe Lieberman (Democrat, Connecticut) called for a doubling of funding in research and development, while Newt Gingrich (Republican, Georgia), Speaker of the House of Representatives, identified biomedical research as one of three areas on which the government should spend more money (the military and new roads being the other two).

\section{Investment}

Real impetus for such investment has been slow to materialize in the Congress. A brief action plan issued last week by the Senate Republican leadership found room for a mischievous proposal to foist the name of Ronald Reagan on Washington National Airport, but not for the Gramm-Lieberman bill. But over the Christmas period, Clinton's conversion became complete. Revised budgetary projections allowed the administration to plan for new investments in science without creating a budget deficit. Clinton's State of the Union address last week was punctuated with references to research and culminated in a eulogy to science's ability to shape the new millennium.

Political rhetoric about the importance of science tends to be ignored by a press that is simultaneously bored by and suspicious of it. But the rhetoric, and the soaring approval ratings that Clinton enjoyed after the State of the Union address, should interest all denizens of science policy. It seems that the conventional wisdom that the public is not interested in science; that there are no votes in it; that it carries no political capital — has recently been turned on its head. This year in the United States, the Congress and the administration are in a race to win credit for spending more money on science.

Of course, they have extra money - other people's money - to spend. They haven't had to do things the hard way, for example by clawing back some of the $\$ 18$ billion that the United States spends each year on a grossly inefficient network of government laboratories that neither Clinton nor the Congress has the guts to reform.

Indeed, few countries have the budgetary freedom to follow the United States' lead. But there are a couple of things from which they can learn, as they observe this latest expansion of the US research system. The first is the success of a flexible, multifaceted university system, in which public and private establishments compete freely and fiercely for money and students (see Nature 391, 8; 1998). The second is a set of research agencies such as NIH and NSF, both with an enviable record of fairness in awarding grants to the universities. Clinton is showing that money spent on science, if distributed wisely and fairly, can win public approval. The principle is universal. 